\title{
Parallel molecular genetic analysis
}

\author{
Steven E M CK enzie $e^{1,2}$, Elaine M ansfield ${ }^{3}$, Eric R appaport ${ }^{4}$, Saul Surrey ${ }^{1}$ and \\ Paolo Fortina ${ }^{4}$
}

${ }^{1}$ D epartment of Pediatrics, Thomas J efferson U niversity, Philadelphia, PA and the du Pont H ospital for Children, Wilmington, $\mathrm{DE}$

${ }^{2} \mathrm{D}$ epartment of Chemical E ngineering, U niversity of Pennsylvania School of E ngineering and A pplied Science

${ }^{3} \mathrm{D}$ iaD exus, 3303 O ctavius D rive, Sante Clara, CA , USA

${ }^{4} \mathrm{D}$ epartment of Pediatrics, U niversity of Pennsylvania School of M edicine, Children's H ospital of Philadelphia,

Philadelphia, PA, USA

\begin{abstract}
We describe recent progress in parallel molecular genetic analyses using DNA microarrays, gel-based systems, and capillary electrophoresis and utilization of these approaches in a variety of molecular biology assays. These applications include use of polymorphic markers for mapping of genes and disease-associated loci and carrier detection for genetic diseases. Application of these technologies in molecular diagnostics as well as fluorescent technologies in DNA analysis using immobilized oligonucleotide arrays on silicon or glass microchips are discussed. The array-based assays include sequencing by hybridization, cDNA expression profiling, comparative genome hybridization and genetic linkage analysis. Developments in non microarraybased, parallel analyses of mutations and gene expression profiles are reviewed. The promise of and recent progress in capillary array electrophoresis for parallel DNA sequence analysis and genotyping is summarized. Finally, a framework for decision making in selecting available technology options for specific molecular genetic analyses is presented.
\end{abstract}

Keywords: chip DNA; microarray; mRNA level; capillary array electrophoresis; single nucleotide polymorphism; mutation detection; genetic analysis

\section{Introduction}

Progress from the Human Genome Initiative and related efforts will soon result in the generation of the sequence of all expressed human genes and the identity of many more disease-causing or disease-predisposing

Correspondence: Paolo Fortina, M D, The Children's H ospital of Philadelphia, 310-C A bramson Pediatric R esearch Center, 34th Street and Civic Center Boulevard, Philadelphia, PA 19104-1804, USA. Tel: (215) 590 3318; Fax: (215) 590-3660; E mail: fortina@mail.med.upenn.edu

R eceived 10 N ovember 1997; revised 2 M arch 1998; accepted 31 M arch 1998 mutations. Knowledge of genomes of multiple other eukaryotic and prokaryotic organisms has progressed as well. Increasing attention has been devoted to parallel molecular genetic analysis methods in order to facilitate the search for multiple genetic alterations at the same time and to advance functional genomics (assessment of gene expression in specific tissues, during development, or in disease states). This review summarizes recent developments in parallel molecular genetic analysis of interest to human genetics.

Functional genomics studies increasingly necessitate obtaining the results of multiple molecular genetic analyses at the same time. For example, genes which 
cause human diseases may contain many different mutations linked to the phenotype, and efficient strategies to scan for these mutations are needed. Furthermore, thousands of genes are expressed in any given cell. D ifferences in gene expression between cells accompany both normal development and development of the malignant cell phenotype. Methods for rapid identification of differentially expressed genes will lead to increased understanding of cell development and perhaps better therapy for cancer. Parallel molecular genetic analysis provides simultaneous information about many genes. Parallel analyses can also provide large amounts of information from small amounts of starting cellular material. The concept of parallel is distinct from but related to that of high throughput, which results in the generation of large amounts of molecular genetic information per unit time. It is possible to have a parallel process which is not high throughput if it takes a long time to obtain information about multiple genes. Conversely, most high-throughput processes are parallel, because serial molecular genetic analyses will tend to increase the overall time needed. Methods in which multiple wet biochemical steps within a single tube or microwell for each molecular analysis are followed by gel electrophoresis of radiolabeled products and then development of a gel image by autoradiography have been standard in molecular genetic analysis, but such methods are intrinsically low throughput. In this review we examine several methods of parallel molecular genetic analysis which are of increasing importance in a number of fields. ${ }^{1-5}$ D NA microarrays, capillary array electrophoresis, mass spectrometry, homogeneous solution assays and hybrids of these methods are all particularly promising technologies.

We begin with DNA microarrays with their myriad uses, then move to parallel mutation detection methods and gene expression profiling methods that do not use microarrays, and finally capillary array electrophoresis approaches to DNA sequence analysis and microsatellite-based genotype analysis. Generalizable highthroughput analytic approaches accessible to any laboratory with molecular genetics expertise will be highlighted. A reas which will not be discussed and for which the reader is directed to recent reviews or references include gene expression profiling in situ, ${ }^{6}$ protein expression profiling using $2 \mathrm{D}$ gels and mass spectrometry analysis, ${ }^{7-9}$ parallel cellular and nucleic acid sample preparation, ${ }^{10-12}$ and bio-informatics approaches to data processing and interpretation. ${ }^{13-15}$

\section{DNA Microarrays}

DNA microarrays have been variously called DNA chips and DNA biochips. The common denominator is a solid platform with a set of immobilized nucleic acid species that participates in a solid-fluid interfacial interaction with a solution of complementary nucleic acid targets. Uses of the DNA microarray include mutation and polymorphism detection, definition of gene expression profiles, genotyping, defining gene organization and mapping, and D NA sequence analysis of previously uncharacterized regions, among others. $^{16-30}$ Since a high density of genes can be studied in parallel, only a small amount of sample is needed. This technology is mostly robotic driven; consequently it can easily be introduced into many research and clinical laboratories.

\section{Mutation and Polymorphism Detection}

$\mathrm{M}$ icrochips consisting of ordered arrays of oligonucleotide probes have been applied to hybridization-based mutation detection schemes. ${ }^{16-39}$ This approach represents in some sense a miniaturization of the use of immobilized oligonucleotides in 96 well plates with several important technical and conceptual differences. With glass or silicon chips, a high degree of parallel array formation increases the information content. With a high number of closely related oligos on a surface, information about partial matches may also be obtained when perfect match duplex values are obtained with fluorescence. F urthermore, the PCR step which is often used to generate reagents for annealing to immobilized probes can now be done in a silicon chip microenvironment. ${ }^{40-42}$

The DNA microarray technique has been used to analyze the entire human mitochondrial DNA, ${ }^{24}$ to detect polymorphisms in the HIV-1 clade $B$ protease gene, ${ }^{25}$ and to detect mutations in $\mathrm{BRCA} 1,{ }^{26,36}$ the cystic fibrosis transmembrane receptor gene and p53. ${ }^{23,34}$ In an extension of DNA microarray technology, Pastinen and colleagues reported allele-specific detection of 12 common disease-causing mutations in the Finnish population using a microarray and singlenucleotide extension. ${ }^{43}$ D etection of beta-globin gene alleles and mutations has also been reported by several groups. ${ }^{28,44,45}$

\section{Gene Expression Profiling}

The potential for this type of gene expression chip is enormous. There are at least three things one wants to know about an mR NA in a cell. Is it present or absent? What is its quantitative level of abundance? What 
difference is there in this level between two different cellular samples? Parallel mR NA expression monitoring by DNA microarray methods has been reported by several different groups with different approaches. Two papers in the peer-reviewed literature summarize the A ffymetrix experience in the gene expression area. ${ }^{46,47}$ The work demonstrates detection of transcripts at the 1 in 300000 level, equivalent to 1 copy per cell, with a dynamic range between 1000 and 10000 . Fragmented RNA target preparation appears advantageous kinetically, in that information was available with hybridization times as short as 2 hours. For the less abundant transcripts, hybridization up to 20 hours was employed. There is a very high degree of probe redundancy (20 to 300 probe pairs per target) and high complexity in the computational analysis, both of which may relate to the fact that light-directed in situ synthesis currently yields only 3 to $5 \%$ of full-length, correct probe sequence per spot for a 20 mer. They have not reported explicit comparison with alternative probes, such as CDNA fragments or presynthesized oligonucleotides. The generalizability of the method to any laboratory with molecular genetics expertise is limited by the need for photolithography, and adaptability for newly discovered targets is potentially slow and costly since new masks might need to be made.

The Stanford/Synteni groups have published several papers using CDNA arrays to assess gene expression, first in yeast and plants and then in human cells. ${ }^{48-51}$ The two-color approach directly provides information comparing two cellular inputs. The cDNA microarrays are very specific and their array methodologies are adaptable by others [www.cmgm.stanford.edu/pbrown]. A Iterations in a number of interesting genes in cellular pathways in response to extracellular perturbations have been identified. With CDNA probes, the kinetics of hybridization is relatively slow and the detection of low copy number transcripts, which account for the majority of the transcripts in a cell by number, is unclear. The reports cite 1 in 10000 detected on a per mass basis, and one report indicates a 1 in 100000 detection sensitivity on a per mass basis. With a CDNA microarray, splice variants and closely related gene family members may not be distinguished.

Workers at Molecular Dynamics reported gene expression results with their arrayer and scanner at the $\mathrm{H}$ ilton $\mathrm{H}$ ead '97 meeting [www.mdyn.com/posters/hiltonhead97]. In bacterial systems, 2 to 3-fold differences in expression of transcripts at abundance levels as low as 1:300 000 were reliably detected. Custom arraying by the end user, after an initial investment, may meet the needs of many research laboratories. The Molecular D ynamics scanner employs confocal microscopy and a photomultiplier tube and is sensitive to 0.1 attomole of fluorescent dye per square micron. ${ }^{52}$

For microarray methods for mRNA detection and quantitation, gene discovery efforts may benefit from arraying probes for potentially all the expressed genes in the human genome. Even before the whole human genome is sequenced, the huge repertoire of expressed sequence tagged sites (ESTs) can be arrayed and studied. ${ }^{48,53}$ Such a chip can be used to study gene expression during development, disease states and in normal metabolic homeostasis. L ater, disease-targeted, user-adaptable arrays with probes for several hundred targets may be most useful in the clinical and biological research laboratories.

\section{Other Anticipated Uses of DNA Microarrays}

These include genetic linkage, forensic identification, pathogen identification, sequence analysis by hybridization of previously uncharacterized regions and comparative genome hybridization. ${ }^{54-57}$ In addition, SingleNucleotide Polymorphism (SNP)-based tests are adaptable to the microarray. The use of Southern blotting and detection of restriction fragment length polymorphism (RFLP) markers provided an initial relatively low resolution human genetic map for linkage analysis. These markers have largely been replaced by simple sequence repeat or microsatellite markers which are both simpler to run and are more highly polymorphic (more informative so fewer markers must be run to derive the same degree of confidence of linkage in gene discovery studies). The microsatellite map in human genetics is now quite dense, for example, $\mathrm{Dibs}^{58}$ recently published the primer sequence and allele size ranges of 5264 microsatellite markers. Consequently, microsatellite genotyping has quickly become adopted in linkage analysis, disease association studies, and in the study of altered profiles diagnostic of certain cancers (evidence of loss of heterozygosity $(\mathrm{LOH})$ or microsatellite instability (M SI). Thus, the microsatellite markers are the current method of choice for many molecular genetic research projects and provide the basis of a much more dense and powerful 'second generation' genetic map. However, microsatellite typing generally requires electrophoretic separation of the PCR -amplified markers in very high-resolution gels, a labor intensive and time-consuming process when slabgel electrophoresis systems are used. Consequently, so-called 'third generation' marker sets are under 
development at several genomic research institutes including the Whitehead Institute (Boston, MA) and G enSet (Paris, France).

The third-generation markers are single-nucleotide polymorphisms (SNP). SN P markers are fundamentally the same as the R FLP markers (base substitutions) but with improvements in detection methods, and are now identified and screened without the use of electrophoresis or Southern blotting. SNP markers can be detected in microplate or microarray-based formats. The inherent variability within the human genome results in base substitutions at approximately $1 \mathrm{~kb}$ intervals. When alternative alleles (base substitutions) have reached a frequency of $30 \%$ or greater, they can be very useful in genetic analysis. With the very high density of these markers in the genome, it is possible to determine regional haplotypes (ordered alleles that cosegregate along a common stretch of chromosome). $\mathrm{H}$ aplotype mapping helps compensate for the lower informativeness of each SNP marker relative to the microsatellite markers. Nevertheless, it is estimated that a 4-CM map of 750 SN P markers will be required to provide the same degree of genetic information as a 10-cM map of approximately 300 microsatellite markers. $^{56}$ The primary motivation for developing a third generation map is that the SN P markers are much more amenable to automation and detection on array-based systems. For example, the Whitehead Institute, M illennium and A ffymetrix have an active program identifying and mapping SNP markers using genomic clones which are physically mapped. Similarly, GenSet in collaboration with A bbott Laboratories also have an SNP marker development program with the goal of identifying up to 30000 SNP markers in the human genome by the end of 1999.

A set of SNP markers uniformly distributed across the genome would have additional applications besides linkage analysis. For example, the use of a 10000 SN P marker set would permit a genome-wide scan for loss of heterozygosity $(\mathrm{LOH})$ at a resolution of under $1 \mathrm{M}$ base (average spacing of the SNP markers would be 300000 nucleotides). This would be a higher resolution $\mathrm{LOH}$ scan than is currently possible using comparative genome hybridization ( $\mathrm{CGH}$ ) carried out using cytogenetic approaches. ${ }^{57}$ By strategically positioning the SNP markers to deletion prone regions of the genome and/ or to known locations of oncogenes, the utility of this approach to $\mathrm{LOH}$ scanning could be further improved. Tightly clustered SNP markers within large genes that lead to rare genetic disorders would provide an alternative method for a linkage-based strategy for disease diagnostics particularly in new mutation disorders (each family has a unique, uncharacterized mutation). For example, the dystrophin gene is approximately $2.4 \mathrm{M}$ base in size and five microsatellite markers are used to follow intragenic recombination in families where either Duchenne or Becker muscular dystrophy are segregating and the responsible mutation fails to be detected using standard exon-screening tests. ${ }^{59-61}$ A pproximately 24 polymorphic SN P markers would be expected to be found within the dystrophin gene. These would naturally have tighter spacing than the current set of intragenic microsatellite markers. By scoring the alleles at the SN P markers, the haplotype of the disease-carrying allele could be identified. A linkage-based method of diagnosis may prove more reliable than a mutation screening-based method in the difficult case of accurately providing diagnosis when the disease-causing gene is very large. Similarly, complex disorders which have multiple genes involved might permit rapid diagnosis using a linkage-based approach. For example, it is estimated that there are 50 genes responsible for inherited deafness. By haplotyping in the vicinity of known genes that could contribute to this disorder, fewer family members might be required to identify which gene is involved for any one family.

\section{Research and Development Issues in DNA Microarrays}

Research and development issues in DNA microarrays that operate by hybridization have been the probes (the immobilized species), the targets (the solution-phase reverse complements of the surface probes), the surfaces, the detection labels, the hybridization conditions, and the detection principle. To our knowledge, 12 separate groups worldwide including our own to date have published the operating details of their microarrays. Probes are obtained by synthesis in situ or deposition of pre-synthesized molecules. Two main types of synthesis in situ have been described: lightbased combinatorial ${ }^{16,62}$ or physical combination. ${ }^{29,63}$ D eposition of pre-synthesized oligonucleotides, ${ }^{20,44,64,65}$ CDNA s ${ }^{48-51}$ or nucleic acids with other base and backbone modifications such as PNA $s^{66-68}$ have been reported. Oligonucleotide probes appear to benefit from spacer arms that link the nucleic acids to the surface. $^{20,44,69}$ Targets have been single- or doublestranded DNA or RNA. A few investigators have explicitly examined varied hybridization conditions. ${ }^{70,71}$ A variety of surfaces have been described, ranging from glass to silicon to plastic to paper to silanized 
glass. ${ }^{16,20,44,72,73}$ There is a multitude of detection labels, radioactive and light-based. A dvantages accrue to the use of light-based detection labels. Detection labels have been based on fluorescence or chemiluminescence, and both primary (label on the target) and secondary (label on a molecule which binds a group on the target or duplex) detection are in use. ${ }^{74} \mathrm{D}$ etection devices include the proximal $C C D,{ }^{64,75}$ CCD-microscope, ${ }^{30,44}$ and PM T-confocal microscope ${ }^{21-26}$ systems.

$D$ iscriminating single-base mutations from normals and especially heterozygotes is fraught with difficulties. We and others have seen unexpected and largely unexplainable hybridization patterns when a given target is hybridized to a series of probes with overlapping sequences. ${ }^{44,76,77} \mathrm{M}$ any examples have concentrated on the difficulties of detecting point mutations. However, similar statements could be made about present techniques for quantitating other important molecular genetic features, such as the absolute expression levels of particular mR NA s. In each case, hybridization alone, while powerful, is unlikely to be capable of providing a complete and unambiguous answer. We and others are turning to combined hybridization and reaction in situ: single-nucleotide extension (SNE), ${ }^{43,78}$ $P C R$ in situ, ${ }^{79-81}$ reporter/quencher uncoupling chemistry (R/Q ), ${ }^{82}$ and ligase chain reaction (LCR) ${ }^{83}$ among others. We designate microarrays that operate by hybridization that follows diffusion of targets to their cognate probes as first generation DNA microarrays. Second generation microarrays have one or more of the following features: active capture of targets, eg by electric field, and hybridization coupled to reaction. There has been a lot of empiricism, but also a considerable contribution to microarray design by fundamental studies. ${ }^{35,44,45,69,72,73,76,84-87}$ The capture rate of a nucleic acid in solution, J (moles $\left./ \mathrm{cm}^{2}\right)$, by its reverse complement immobilized on a solid surface, when the number of surface 'probe' molecules is in molar excess, is given by: $:^{84,85}$

$$
J=\left(\pi \gamma \mathrm{D}_{3} / 4 \mathrm{H}\right) \mathrm{C}_{0} \mathrm{t}
$$

Molecular biologists with experience in solutionphase hybridization studies understand the dependence on $\mathrm{C}_{0} \mathrm{t}$. This theoretical result places physical observables in the factors other than $\mathrm{C}_{0} \mathrm{t}$ which determine capture and hybrid formation specifically at the solidliquid interface. This J is the initial rate - eventually the capture saturates at an inverse exponential rate, but most detection can and does operate before that point is reached. The parameter $\gamma$ incorporates all of the 3 - and 2-dimensional diffusion effects, adsorption at the surface, probe density within a site, probe molecular length and target length. $D_{3}$ is the solution diffusion coefficient of the target. The smaller the target, the larger is $D_{3}$ and the more rapid its capture by the diffusive mechanism, supporting the empirical practice of fragmenting into smaller targets. ${ }^{21-26}$ Fragmentation also minimizes secondary structure, an effect discussed later. $\mathrm{H}$ is the boundary layer, often in the length scale of tens of microns, over which the concentration changes from its bulk solution value to that right at the interface. D ecreasing $\mathrm{H}$, for example by stirring or by 'excluding volume' from the bulk solution with amphipathic organic molecules like PE G or phenol increases capture. ${ }^{44,86,88}$ If a second mechanism of capture at the surface is included, like electric field, capture can be enhanced. This underlies another published approach, which is very rapid but employs more complex chip manufacture and operation. ${ }^{70}$ The side-on orientation of DNA molecules on common silanized surfaces has been observed experimentally. ${ }^{87}$ Further progress in rational design from biophysical and biochemical fundamental study is anticipated.

\section{Non Microarray-based Parallel Mutation Detection Methods}

DNA sequence variation detection methods share several conceptual issues, such as whether a known change is being detected or a region is being scanned for new mutations, whether the end user of the method is a clinical laboratory or a research laboratory, whether the change to be identified is a disease-causing mutation or a polymorphism, and whether the cellular sample is homozygous, hemizygous or heterozygous for the change.

A wide variety of PCR -based mutation detection methods have been described. ${ }^{89,90}$ In general the mutation detection methods can be grouped according to whether they are scanning or allele specific. Within the scanning methods, they can be grouped according to which principle of operation they employ. Wellknown applications for mutation screening include direct DNA sequence analysis, denaturing-gradient gel electrophoresis (DG GE), ${ }^{91}$ single-stranded conformation polymorphism (SSCP) ${ }^{92}$ and its variants dideoxyfingerprinting $(\mathrm{ddF})^{93}$ and restriction endonuclease fingerprinting ${ }^{94}$ heteroduplex analysis including chemical cleavage of mismatches $(\mathrm{CCM})^{95}$ and endonuclease 
mismatch cleavage (EMC), ${ }^{96}$ and R Nase A cleavage. ${ }^{97}$ A utomated fluorescence-based D NA sequence analysis can generate 600 to 800 nucleotides of sequence data per reaction, and in some sense is parallel in that multiple gel electrophoresis lanes can be analyzed at the same time, as is true for SSCP, DG GE and some of the other methods. A llele-specific mutation/polymorphism detection methods include direct D NA sequence analysis, ${ }^{98}$ reverse dot-blot with allele-specific oligonucleotide hybridization, ${ }^{99}$ allele-specific PCR amplification, ${ }^{100}$ oligonucleotide ligation amplification (OLA), ${ }^{101}$ artificial introduction of restriction sites, ${ }^{102}$ ligase chain reaction $^{103}$ and DNA minisequence analysis. ${ }^{104-106}$ PCR-OLA has been applied to DNA diagnostics, ${ }^{107}$ genetic mapping using biallelic markers ${ }^{108}$ and YAC library screening. ${ }^{109} \mathrm{~A}$ variation on PCR-OLA to increase sample throughput makes use of sequencecoded separation. ${ }^{101}$ Fluorescence-based DNA minisequence analysis facilitates detection of mutated sequences. ${ }^{110,111}$ Limited primer-extension techniques, primer-guided nucleotide incorporation, single-nucleotide primer extension (SNPE) or solid-phase minisequencing were developed previously to detect point mutations by single-base extension of the primer at the site of the mutation. ${ }^{104-106}$ These procedures use a primer designed to hybridize just 5 ' of the nucleotide to be tested. The primer is extended by a single dyelabeled dideoxynucleotide, thereby indicating the identity of the target nucleotide in the template. Fluorescent extension products are then detected following electrophoresis on denaturing polyacrylamide gels. Fluorescence analysis of the incorporated dye tag reveals the identity of the template nucleotide immediately 3 ' to the primer site. There are recent examples of the application of the single nucleotide extension principle to the microarray format. ${ }^{43,78}$

Two newer methods are cleavase fragment length polymorphism (CFLP) and multiplex allele-specific diagnostic assay (M A SDA ). CFLP is a scanning methodology, while MASDA is an allele-specific methodology. CFLP is in the general category of secondary structure-specific mutation detection. Whilst SSCP reflects structure-specific mobilities, CFLP reflects structure-specific nuclease cleavage. ${ }^{112}$ MASDA is a multistep process in which multiplex gene-specific $P C R$ is followed by a forward dot-blot using a pool of radiolabeled A SO probes. ${ }^{113}$ A fter the dot-blot, verification of which oligo in the pool hybridized to an array spot is performed by a biochemical fingerprinting assay.
To compare and contrast all of these methods with DNA microarray methods of mutation detection, it is clear that many non microarray methods are up and running now while DNA microarray methods have just passed proof-of-principle and are undergoing initial dissemination. (CE/CAE are discussed below.) A utomated fluorescence-based DNA sequence analysis continues to have many desirable features. Gel-based methods that use multicolor fluorescence consolidate separation with detection and have the advantage that software analysis can be built in. The special conditions required for running assays such as DGGE and SSCP have made their implementation on machines designed originally for automated DNA sequencing more problematic. The absence of a cooling unit on these sequencers originally required SSCP gels to be run for long times at very low current to avoid denaturing the annealed species, ${ }^{114}$ although other investigators have made modifications to their machines to provide refrigeration capabilities and permit shorter run times. $^{115,116}$ Some technical modifications were also necessary to reduce background problems in the implementation of the fluorescent versions of the $\mathrm{CCM}^{117}$ and dideoxyfingerprinting assay. ${ }^{118} \mathrm{M}$ ost recent versions of automated sequencers including capillary array electrophoresis equipment (CAE) have built-in temperature control, which permits SSCP and other temperature-dependent applications to be accomplished. Many of these assays can be done using fluorescently-labeled reactions and appropriate detection systems, resulting in automated data collection and semi-automated analysis. ${ }^{119}$ In most cases, the use of fluorescence in these assays is limited only by the ability to label the species in an efficient manner without causing background problems. ${ }^{120}$ How robust each of these methods are (accuracy, reproducibility and reliability) is of concern to end-users and has limited the acceptance of any one scanning or allele-specific method in molecular genetics laboratories. M icroarrays have the inherent advantage that they can do both scanning and allele-specific mutation detection while consolidating the reaction step with detection, thus skipping a distinct separation step. Since physical localization is intrinsic to a spatially addressable array, there is no electrophoretic separation. Currently, microarrays avoid radioactivity and are readily operated with multicolor detection, which increases the amount of information per spot and per unit time. O ne major distinction between mutation detection methods in the future may be microarrays vs homogeneous 
solution arrays that perform consolidated reaction and detection with no separation step (for example, 'molecular beacon'/R eporter-Q uencher systems). ${ }^{38,82,121}$ Since these homogeneous assays are still under development, how parallel, small and fast these are in comparison to microarrays remain to be determined. $M$ ass spectrometry-based methods have also been proposed and are under development. ${ }^{31-33}$

\section{Non Microarray-based Parallel Gene Expression Profiling}

A nalysis of mR NA, in particular differences in expression patterns between cell types, is an area of intense interest. At this time this is almost exclusively a research laboratory enterprise, not one for the clinical molecular diagnostics laboratory. Several common methods of RNA analysis are not inherently designed as parallel molecular genetic assays, such as northern blot analysis, nuclease protection assays and RT-PCR . Beyond the DNA microarray work described in the preceding section, there are a number of parallel gene expression profiling methods in use in many laboratories. These include

(1) subtractive hybridization and its variants, recently reviewed in Sagerstrom et al, ${ }^{122}$ in which comparison with other established methods was discussed;

(2) differential display and its variants;

(3) differential screening of CDNA libraries;

(4) large-scale sequencing of CDNA clones or 3'-end fragments thereof;

(5) representational difference analysis (RDA); and

(6) serial analysis of gene expression (SA GE).

Subtractive hybridization (SH), differential display, differential screening, large-scale sequencing and R DA have been in the literature for several years, reviewed recently and are in use in many laboratories. R ecent variations of these methods to improve their performance have been described. I mprovements in subtractive hybridization may come from positive selection and so-called suppressive hybridization methods. ${ }^{123}$ Elements of suppressive hybridization have also been combined recently with elements of differential screening. A variant of differential display PCR has been published recently called ordered dd-PCR. ${ }^{124} \mathrm{~N}$ ormal- ized or self-subtracted libraries appear to enhance performance in large scale DNA sequencing. ${ }^{122}$ In commercial research labs, large-scale cDNA sequencing has been reported to identify many novel CDNA S. $M$ uch has been learned from the SA GE method. ${ }^{125-127}$ SA GE works by cloning and sequencing strings of 9 to $11 \mathrm{bp}$ fragments from cD NA libraries, and uses statistical sequence analysis first to assign the fragments uniquely to transcripts and then to calculate abundance. $\mathrm{M}$ any of the findings from classic hybridization studies in the 1970s concerning the number and abundance classes of mRNA $s$ in cells have been confirmed; ${ }_{i}^{122,128}$ $86 \%$ of transcripts by number are present at less than 5 copies per cell. Of the approximately 15000 distinct transcripts in a cell, 1-2\% differ in cells of closely related origins. If cells of more disparate origins are compared, the percentage of differentially expressed transcripts may rise to 3-5\%. Differentially expressed transcripts occur in all abundance classes. SAGE is unfortunately not high throughput and thus is not amenable to the clinical laboratory.

\section{Capillary Array Electrophoresis Methods for DNA Sequence Analysis and Microsatellite Genotype Analysis}

Recently, fluorescence detection systems have been coupled with the speed and convenience of capillary electrophoresis (CE) systems which have potential for rapid, high-throughput genetic analysis without the constraints and disadvantages of slab-gel based systems. These systems have already been used to analyze fluorescent sequencing reactions and a variety of dyelabeled fragments. ${ }^{129,130} \mathrm{M}$ ultiple arrays of capillaries and advances in separation matrices will further enhance resolution, sample throughput and decrease run times. Capillary technology also has the potential to be engineered on a microchip scale, decreasing electrophoresis times by an order of magnitude. ${ }^{131-133}$

$M$ athies and co-workers developed a laser-excited, confocal fluorescence imaging system for DNA sequencing or mapping fragments in a planar array of several capillaries simultaneously, a technology known as capillary array electrophoresis (CA E) ${ }^{134,135}$ CA E offers an excellent opportunity to develop instrumentation capable of striking increases in efficiency and convenience for DNA analysis. Molecular Dynamics, extending the work in $C A E$, is developing instrument 
systems capable of scanning across 48-96 parallel capillaries. $^{136,137}$ This could increase throughput of fluorescence D NA sequencing and mapping by over an order of magnitude.

Labor-intensive steps of fragment separations are eliminated by CA E. Slab gel preparation is replaced by automated capillary filling using a low-viscosity gel matrix, refillable capillaries and a pressurized gel-filling station. ${ }^{138}$ The process is complete within 10 minutes without user intervention. Gel loading, another tedious, labor-intensive step, is replaced with electrokinetic injection of 48-96 samples at a time. Capillaries are then purged and refilled using the gel-filling station on the instrument. Thus, the increase in sample throughout is not limited to electrophoresis time, but all steps of gel preparation and sample loading. U se of 4-color chemistries has been used in DNA sequencing and permits detection of multiple genetic markers with overlapping size ranges. Multiplexing strategies increase sample throughput and conserve reagent costs when done during the PCR amplification step.

E stimated time from capillary filling, sample injection, separation and refilling of the capillary for the next run is under 1.5 hours. ${ }^{138,139}$ With continuous operation (16 runs per day), 1536 samples could be processed per day by CAE. By using the 4-color multiplex strategy that has been applied to slab-gel electrophoresis systems, 27648 genotypes could be determined per day (1536 samples $\times 3$ colors of labels $\times 6$ loci/color) compared to a maximum of 4 runs in 24 hours on current slab-gel systems. The CA E approach translates into 2304 genotype analyses per day ( 128 samples $\times 3$ colors of labels $\times 6$ loci/color). Thus, CAE systems would have a ten-fold greater throughput and require much less hands-on time for operation.

\section{Conclusions}

We have witnessed the initial impact of parallel molecular genetic analysis, increasing sample throughput and facilitating semi-automated data analysis. M ore importantly, these new technologies, such as DNA microarrays and capillary array electrophoresis, replace standard molecular biology platforms and may lead to further technological advances in genetic analysis. In addition, recent developments in scanner technology promise to reduce the time needed to obtain large amounts of information at the same time.

Some specific comparative strengths and weaknesses of analytic technologies for mutation detection and gene expression profiling have been listed in the individual sections. Here we summarize a framework for decision making in selecting available technology options, which is tabulated in Table 1 for seven of the most common molecular genetic tasks. Our philosophy is to list the technology options for which there is a body of literature and to identify the criteria for

Table 1 Parallel molecular genetic analysis - framework for decision making in selecting available technology options

\begin{tabular}{|c|c|c|}
\hline$\overline{\text { M olecular genetic task }^{1}}$ & A nalytic technology options & Criteria for selection by end users 3 \\
\hline $\begin{array}{l}\text { A M utation detection, allele-specific } \\
\text { B M utation detection, scanning known gene(s) } \\
\text { C Sequence analysis, previously unknown region } \\
\text { D Polymorphism scoring, eg for linkage } \\
\quad \text { microsatellite (M S) } \\
\quad \text { single nucleotide polymorphism (SN P) } \\
\text { E G ene expression profiling } \\
\text { F G ene copy number determination }\end{array}$ & $\begin{array}{l}1,2,3,4,5,6,7 \\
1,3,4 \\
1,3,4 \\
3,4,5,7 \\
1,2 \\
1 \\
1,4,5\end{array}$ & $\begin{array}{l}A, B, C, D, E, F \\
A, D, E, F \\
A, D \\
A, B, C \\
A, C, D \\
A, C, D, E, F \\
A, C\end{array}$ \\
\hline $\begin{array}{l}\text { Key: } \\
\text { A } 18,19,31-33,35,36,43,45,63,78,117 \\
\text { B } 17,21-29,31,34,36,37,39,42,55,64-66,70-72,75 \\
\text { C } 37,39,129,133,137 \\
\text { D (MS) 31, 131, 132, 138, } 139 \\
\text { D (SNP) 20, 30 } \\
\text { E } 46-54 \\
\text { F } 57,83,121\end{array}$ & $\begin{array}{l}\text { 1 D NA microarray, 1st generation } \\
\text { 2. D NA microarray, 2nd generation } \\
3 \text { R apid gel-based systems } \\
4 \text { Capillary array electrophoresis } \\
5 \text { H omogeneous solution assay } \\
6 \text { M ass spectroscopy } \\
7 \text { H ybrid of the above }\end{array}$ & $\begin{array}{l}\text { A Cost - upfront } \\
\text { B C ost - ongoing operation } \\
\text { C H ow parallel } \\
\text { D H ow high-throughput } \\
\text { E H ow adaptable } \\
\text { F H ow generalizable }\end{array}$ \\
\hline
\end{tabular}

1Tasks range from allele-specific to genome-wide; additional uses in research and development include forensic identification, pathogen identification, microsatellite instability analysis and D NA methylation analysis.

${ }^{2} \mathrm{R}$ eferences based primarily on the peer-reviewed literature up to 01/31/1998.

3E nd users include biomedical research laboratories, molecular diagnostic clinical laboratories and the pharmaceutical industry. 
selection by end users. The literature in this area is exploding rapidly, and our tabulation is as of 30 January 1998. U pdates will clearly be needed in the future, and other recent reviews offer alternative opinions. ${ }^{52,140-143}$ The technology option which is best will be driven by different criteria for different users. The relative importance of upfront and ongoing operational costs and how adaptable and generalizable a technology is will depend on whether one is in an academic biomedical research center, a clinical molecular diagnostics laboratory or the pharmaceutical industry, among other venues. By generalizable we mean able to be used by any laboratory with current molecular genetics expertise. By adaptable we mean able to be used for new genes or by multiple users with different interests. In first generation DNA microarray technology, the upfront costs for an arrayer and a scanner system are of the order of $\$ 200000-250000$. Chip costs vary between premade and marketed and making one's own. High volume use keeps the per chip cost low, and then operator time and sample preparation become significant ongoing operational costs. Capillary array electrophoresis units are expected to cost under $\$ 200000$ initially, and operating costs will be comparable to gel-based systems. In summary, in Table 1 we provide a framework by which readers can make their own best decisions.

We anticipate that in the future consolidation of function and miniaturization will continue. Consolidation of the functions of sample preparation, target amplification and labelling, real time detection, analysis and informatics will result in very powerful tools. A s the $\mathrm{H}$ uman $\mathrm{G}$ enome I nitiative meets its objectives, we may find a return to a focus on parallel molecular genetic technologies for specific diseases and conditions, eg all cardiovascular disease susceptibility genetic changes, all molecular alterations present in leukemia, all genetic variations relevant to drug metabolism, etc.

\section{Acknowledgements}

This work was supported in part by a grant from the Ethel B rown Foerderer Fund for Excellence, by $\mathrm{NIH}$ grants P60-H L 38632, P30-H G 00425, R 01-DK 16691, and SBIR R 43NS/M H 34589, a Special Opportunity A ward of the Whitaker Foundation and by the Nemours Foundation.

\section{References}

1 Lander ES: The new genomics: global views of biology. Science 1996; 274: 536-539.
2 Cotton R G: Slowly but surely towards better scanning for mutations. Trends G enet 1997; 13: 43-46.

3 Fodor SPA: Massively parallel genomics. Science 1997; 277: 393-395.

4 G offeau A: DNA technology: molecular fish on chips. Nature 1997; 385: 202-203.

5 Cheng J, Fortina P, Surrey S, Kricka LJ, Wilding P: $M$ icrochip-based devices for molecular diagnosis of genetic diseases. M ol Diagnosis 1996; 1: 1-18.

6 Strachan T, A bitbol M, Davidson D, Beckmann J S: A new dimension for the human genome project: towards comprehensive expression maps. Nat Genet 1977; 16: $126-132$

7 A nderson NG, A nderson NL: Twenty years of 2D electrophoresis: past, present and future. Electrophoresis 1996; 17: 443-453.

8 R oepstorff $P$ : M ass spectrometry in protein studies from genome to function. Curr O pin Biotech 1997; 8: 6-13.

9 Shevchenko A, Jensen ON, Podtelejnikov AV et al: L inking genome and proteome by mass spectrometry: large-scale identification of yeast proteins from two dimensional gels. Proc Natl Acad Sci USA 1996; 93: 14440-14445.

10 Northrup M A, Ching M T, White R M, Watson RT: D NA amplification in a microfabricated reaction chamber. In Transducers '93, 7th International Conference on Solid State Sensor A ctuators. Yokohama, Japan, June 7-10, 1993, pp 924-926.

11 K ricka LJ, N ozaki O, H eyner S, G arside WT, Wilding P: A pplication of a microfabricated device for evaluating sperm function. Clin Chem 1993; 39: 1944-1947.

12 Wilding $P$, Shoffner MA, K ricka LJ : PCR in a silicon microstructure. Clin Chem 1994; 40: 1815-1818.

13 B enton D: Bioinformatics: principles and potential of a new multidisciplinary tool. Trends Biotech 1996; 14: 261-272.

14 Palsson BO: What lies beyond bioinformatics? $N$ at Biotechnol 1997; 15: 3-4.

15 Rawlings CJ, Searls D B: Computational gene discovery and human disease. Curr O pin G enet Develop 1997; 7: 416-423.

16 Fodor SPA , R ead J L, Pirrung M C, Stryer L, L u A T, Solas $D$ : L ight-directed, spatially addressable parallel chemical synthesis. Science 1991; 251: 767-773.

17 Southern EM, Maskos U, Elder JK: A nalyzing and comparing nucleic acid sequences by hybridization to arrays of oligonucleotides: evaluation using experimental models. G enomics 1992; 13: 1008-1017.

18 Maskos $U$, Southern EM: A novel method for the analysis of multiple sequence variants by hybridization to oligonucleotides. Nucleic Acids Res 1993; 21: 2267-2268.

19 Maskos U, Southern EM: A novel method for the parallel analysis of multiple mutations in multiple samples. N ucleic A cids Res 1993; 21: 2269-2270.

20 Guo Z, Guilfoyle RA, Thiel AJ, Wang R, Smith LM: $D$ irect fluorescence analysis of genetic polymorphisms by hybridization with oligonucleotide arrays on glass supports. Nucleic A cids Res 1994; 22: 5456-5465.

21 Pease AC, Solas D, Sullivan EJ, Cronin M T, H olmes CP, Fodor SPA : Light-generated oligonucleotide arrays for rapid DNA sequence analysis. Proc N atl A cad Sci USA 1994; 91: 5022-5026. 
22 Lipshutz RJ, Morris D, Chee $M$ et al: U sing oligonucleotide probe arrays to access genetic diversity. Biotechniques 1995; 19: 442-447.

23 Cronin M T, Fucini SM K, M asino R S, Wespi R M , M iyada CG : Cystic fibrosis mutation detection by hybridization to light-generated DNA probe arrays. H um M ut 1996; 7: 244-255.

24 Chee $M, Y$ ang $R, H$ ubbell $E$ et al: A ccessing genetic information with high-density D NA arrays. Science 1996; 274: 610-614.

25 Kozal MJ, Shah N, Shen N et al: Extensive polymorphisms observed in HIV-1 clade B protease gene using high-density oligonucleotide arrays. Nat Med 1996; 2: 753-759.

26 Hacia JG, Brody LC, Chee M S, Fodor SPA, Collins FS: Detection of heterozygous mutations in BRCA 1 using high density oligonucleotide arrays, two colour fluorescence analysis. N at G enet 1996; 14: 441-447.

27 Yershov G, Barsky V, Belgovskiy A et al: DNA analysis and diagnostics on oligonucleotide microchips. Proc $\mathrm{N}$ atl A cad Sci USA 1996; 93: 4913-4918.

28 Drobyshev A, Moligina N, Shik V, Pobedimskaya D, Yershov G, M irzabek ov A : Sequence analysis by hybridization with oligonucleotide microchip: identification of $\beta$-thalassemia mutations. G ene 1997; 188: 45-52.

29 Southern E M : D NA chips: analysing sequence by hybridization to oligonucleotides on a large scale. Trends $G$ enet 1996; 12: 110-115.

30 Guo A, Liu Q, Smith LM: Enhanced discrimination of single nucleotide polymorphisms by artificial mismatch hybridization. Nat Biotech 1997; 15: 331-335.

31 Little DP, Braun A, O'Donnell MJ, Koster $\mathrm{H}$ : Mass spectrometry from miniaturized arrays for full comparative DNA analysis. N at M ed 1997; 3: 1413-1416.

32 Higgins GS, Little DP, Koster $\mathrm{H}$ : Competitive oligonucleotide single-base extension combined with mass spectrometric detection for mutation screening. Biotechniques 1997; 23: 710-714.

33 Griffin TJ, Tang W, Smith LM: Genetic analysis by peptide nucleic acid affinity MALDI-TOF mass spectrometry. Nat Biotech 1997; 15: 1368-1372.

$34 \mathrm{H}$ ead SR, R ogers $\mathrm{Y}-\mathrm{H}$, Parikh $\mathrm{K}$ et al: Nested genetic bit analysis (N-GBA) for mutation detection in the p53 tumor suppressor gene. Nucleic A cids Res 1997; 25: 5065-5071.

35 Edman CF, Raymond DE, Wu DJ et al: Electric filed directed nucleic acid hybridization on microchips. N ucleic A cids Res 1997; 25: 4907-4914.

$36 \mathrm{H}$ acia J G, M akalowski W, E dgemon $\mathrm{K}$ et al: E volutionary sequence comparisons using high-density oligonucleotide arrays. Nat $G$ enet 1998; 18: 155- 158.

37 Stein A, H ill SA, Cheng Z, Bina M : Simple miniaturized gel system for D NA sequence analysis. N ucleic $A$ cids R es 1998; 26: 452-455.

38 Tyagi S, Bratu DP, Kramer FR: Multicolor molecular beacons for allele discrimination. $N$ at B iotech 1998; 16 : 49-53.

39 D rmanac S, K ita D, L abat I et al: A ccurate sequencing by hybridization for DNA diagnostics and individual genomics. Nat Biotech 1998; 16: 54-58.
40 Shoffner M A, Cheng J, H vichia GE, K ricka LJ, Wilding P: Chip PCR (I): surface passivation of micro-fabricated silicon-glass chips for PCR. Nucleic A cids Res 1996; 24: 375-379.

41 Cheng J, Shoffner M A, H vichia GE, K ricka LJ, Wilding P: Chip PCR (II): investigation of different PCR amplification systems in micro-fabricated silicon-glass chips. Nucleic A cids Res 1996: 24: 380-385.

42 Taylor TB, Winn-D een E S, Picozza E, Woudenberg TM, A lbin $M$ : Optimization of the performance of the polymerase chain reaction in silicon-based microstructure. N ucleic A cids Res 1997; 25: 3164-3168.

43 Pastinen $T$, Kurg A, M etspalu A, Peltonen L, Syvanen A -C: M inisequencing: a specific tool for DNA analysis and diagnostics on oligonucleotide arrays. G enome Res 1997; 7: 606-614.

44 Sanguedolce LA , C han V, M cK enzie S, Surrey S, Fortina $P, G$ raves $D$ : Fundamental studies of DNA adsorption and hybridization on solid surfaces. In: Dinh $S$, De Nuzzio J (eds). Intelligent $M$ aterials and Novel Concepts for Controlled-release Technologies. A merican Chemical Society Symposium Series. 1998, in press. A cademic Press.

45 Sanguedolce LA : Fundamental studies of DNA attachment and hybridization at a solid-liquid interface. U niversity of Pennsylvania, 1997, PhD thesis.

46 Lockhart $D J$, Dong $H$, Byrne $M C$ et al: Expression monitoring by hybridization to high-density oligonucleotide arrays. Nat B iotech 1996; 14: 1675-1680.

47 Wodicka L, D ong H, M ittman M, H o M-H, Lockhart DJ : Genome-wide expression monitoring in Saccharomyces cerevisiae. Nat Biotech 1997; 15: 1359-1367.

48 DeR isi J, Penland L, Brown PO et al: U se of a CDNA microarray to analyze gene expression patterns in human cancer. Nat G enet 1996; 14: 457-460.

49 Schena M, Shalon D, D avis RW, B rown PO : Q uantitative monitoring of gene expression patterns with a complementary DNA microarray. Science 1995; 270: 467-470.

50 Schena M, Shalon D, H eller R, Chai A, B rown PO, D avis RW: Parallel human genome analysis: microarray-based expression monitoring of 1000 genes. P roc N atl A cad Sci USA 1996; 93: 10614-10619.

51 Shalon D, Smith SJ, Brown PO: A DNA microarray system for analyzing complex DNA samples using twocolor fluorescent probe hybridization. G enome R es 1996; 6: 639-645.

52 Castellino A M : When the chips are down. Genome Res 1997; 7: 943-946.

53 Ferguson JA, B oles TC, A dams CP, Walt D R : Fiberoptic DNA biosensor microarray for the analysis of geneexpression. N at B iotech 1996; 14: 1681-1684.

54 Heller RA, Schena M, Chai A et al: D iscovery and analysis of inflammatory disease-related genes using cD NA microarrays. Proc Natl A cad Sci USA 1997; 94: 2150-2155

55 D rmanac R, Drmanac S, Strezoska Z et al: DNA sequence determination by hybridization: a strategy for efficient large-scale sequencing. Science 1993; 260: 1649-1652.

56 K ruglyak $L$ : The use of a genetic map of biallelic markers in linkage studies. N at G enet 1997; 17: 21-24. 
57 Solinas-Toldo S, Lampel S, Stilgenbauer S et al: M atrixbased comparative genomic hybridization: biochips to screen for genomic imbalances. Genes Chromosom Cancer 1997; 20: 399-407.

58 Dibs C, Faure S, Fizames C et al: A comprehensive genetic map of the human genome based on 5,264 microsatellites. Nature 1996; 380: 152-154.

59 Chamberlain J S, Gibbs RA, Rainier JE, Nguyen PN, Caskey CT: D eletions screening of the Duchenne muscular dystrophy locus via multiplex DNA amplification. N ucleic A cids Res 1988; 16: 11141-11156.

60 Beggs A H, Koerig M, Boyce FM, Kurkel LM L : D etection of $98 \%$ of $D M D / B M D$ gene deletions by polymerase chain reaction. $\mathrm{H}$ um $\mathrm{G}$ enet 1990; 86: 45-48.

61 Clements PR, Fenwick R G, Chamberlain J S et al: Carrier detection and prenatal diagnosis in Duchenne and Becker muscular dystrophy families using dinucleotide repeat polymorphisms. Am J Hum Genet 1991; 49: 951-960.

62 McG all G, Labadie J, Brock P, Wallraff G, N guyen T, $H$ insberg $W$ : Light-directed synthesis of high density oligonucleotide arrays using semiconductor photoresists. Proc Natl A cad Sci USA 1996; 93: 13555-13560.

63 Nilsson M, Malmgren $H$, Samiotaki M, K wiatkowski M, Chowdhary B P, L andegren U : Padlock probes: circularizing oligonucleotides for localized DNA detection. Science 1994; 265: 2085-2088.

64 Eggers MD, Hogan ME, Reich RK et al: Gensensors: microfabricated devices for automated DNA sequence analysis. In: Advances in DNA Sequencing Technology. Proceedings SPIE 1993; pp 113-126.

65 Beattie K, E ggers M, Shumaker J et al: Genosensor technology. Clin Chem 1993; 39: 719-722.

66 Weiler J, Gausepohl H, H auser N, Jensen O, Hoheisel JD: Hybridisation based DNA screening on peptide nucleic acid (PNA) oligomer arrays. Nucleic Acids Res 1997; 25: 2792-2799.

67 Wittung $P$, Nielsen PE, B uchardt $O$, E gholm M, Norden $B$ : DNA -like double helix formed by peptide nucleic acid. Nature 1994; 368: 561-563.

$68 \mathrm{~N}$ guyen $\mathrm{H}-\mathrm{K}, \mathrm{A}$ uffray $\mathrm{P}, \mathrm{A}$ sseline $\mathrm{U}, \mathrm{D}$ upret $\mathrm{D}$, Thuong NT: Modification of DNA duplexes to smooth their thermal stability independently of their base content for DNA sequencing by hybridization. Nucleic A cids Res 1997: 25: 3059-3065

69 M askos U, Southern E M : O ligonucleotide hybridisations on glass supports: a novel linker for oligonucleotide synthesis, hybridisation properties of oligonucleotides synthesized in situ. Nucleic Acids Res 1992; 20: 1679-1684

70 Sosnowski RG, Tu E, Butler WF, O'Connell JP, Heller $\mathrm{M}$ J : R apid determination of single base mismatch mutations in D NA hybrids by direct electric field control. P roc Natl A cad Sci USA 1997; 94: 1119-1123.

71 D ubiley S, K irillov E, Lysov Y, M irzabekov A : Fractionation, phosphorylation and ligation on oligonucleotide microchips to enhance sequencing by hybridization. N ucleic A cids Res 1997; 25: 2259-2265.

$72 \mathrm{M}$ atson R S, R ampal J, Pentoney J, Stephen L, A nderson PD, Coassin P: Biopolymer synthesis on polypropylene supports: oligonucleotide arrays. Anal Biochem 1995; 224: 110-116.
73 Chrisey LA, Lee GU, O'Ferrall CE : Covalent attachment of synthetic DNA to self-assembled monolayer films. Nucleic A cids Res 1996; 24: 3031-3039.

74 M ansfield ES, Worley JM, McKenzie SE, Surrey S, Rappaport EF, Fortina P: Nucleic acid detection using non-radioactive labeling methods. $M$ ol Cell Probes 1995: 9: $145-156$.

75 Lamture JB, Beattie KL, Burke BE et al: Direct detection of nucleic acid hybridization on the surface of a charge coupled device. Nucleic Acids Res 1994; 22: 2121-2125.

76 Shchepinov MS, Case-Green SC, Southern E M : Steric factors influencing hybridization of nucleic acids to oligonucleotide arrays. Nucleic Acids Res 1997; 25: $1155-1161$.

77 Lima W F, M onia B P, E cker DJ, Freier SM : Implication of RNA structure on antisense oligonucleotide hybridization kinetics. B iochemistry 1992; 31: 12055-12061.

78 Shumaker J M, M etspalu A, Caskey CT: M utation detection by solid phase primer extension. Hum M ut 1996; 7: 346-354.

79 B ryant $\mathrm{N}$ : U se of PCR method expands to include broad range of diverse applications. $G$ enetic $E$ ngineering $N$ ews 1997; 1: 9,31.

80 A dams CP, K ron S]: M ethod for performing amplification of nucleic acid with two primers bound to a single solid support. M osaic Technologies Inc, W hitehead Institute for Biomedical Research, 1997, USA patent 5641658.

81 L ockley A K, Jones CG, B ruce J S, Franklin SJ, Bardsley $R G$ : Colorimetric detection of immobilised $P C R$ products generated on a solid support. Nucleic Acids Res 1997; 25: 1313-1314.

82 Tyagi S, Kramer FR: M olecular beacons - probes that fluoresce upon hybridization. Nat Biotech 1996; 14: 303-308.

83 Cheng J, Shoffner MA, Mitchelson KR, K ricka LJ, Wilding $P$ : The examination of ligase chain reaction (LCR) products amplified in the silicon chip using entangled solution capillary electrophoresis (ESCE).J Chromatogr A 1996; 732: 151-158.

84 Chan V, Graves DJ, McK enzie SE: The biophysics of DNA hybridization with immobilized oligonucleotide probes. B iophys J 1995; 69: 2243-2255.

85 Chan V, G raves D J, Fortina P, M CK enzie SE : A dsorption and surface diffusion of DNA oligonucleotides at liquid/ solid interfaces. $L$ angmuir 1997; 13: 320-329.

86 Chan V: R eduction of dimensionality processes of D NA hybridization with immobilized oligonucleotide probes. U niversity of Pennsylvania, 1997, PhD thesis.

87 Chan V, M cK enzie SE, Surrey S, Fortina P, G raves DJ : The effect of hydrophobicity and electrostatics on adsorption and surface diffusion of DNA oligonucleotides at liquid/solid interfaces. I Colloid Interface Sci 1998; 203: 197-207.

88 Pontius BW, Berg P: R apid renaturation of complementary DNA strands mediated by cationic detergents: a role for high probability binding domains in enhancing the kinetics of molecular assembly processes. Proc N atl A cad Sci USA 1991; 88: 8237-8241.

$89 \mathrm{Grompe} M$ : The rapid detection of unknown mutations in nucleic acids. Nat G enet 1993; 5: 111-117. 
90 Chehab FF: Molecular diagnostics: past, present and future. Hum Mut 1993; 2: 331-337.

91 Sheffield V C, Cox DR, Lerman LS, M yers R M : A ttachment of a 40-base-pair $G+C$-rich sequence ( $\mathrm{C}$-clamp) to genomic DNA fragments by the polymerase chain reaction results in improved detection of single-base changes. Proc Natl A cad Sci USA 1989; 86: 232-236.

92 Orita M, I wahana H, K anazawa H, H ayashi K, Sekiya T: Detection of polymorphisms of human DNA by gel electrophoresis as single-strand conformation polymorphisms. Proc Natl A cad Sci USA 1989; 86: 2766-2770.

93 Sarkar G, Y oon H-S, Sommer SS: D ideoxy fingerprinting $(d d F)$ : a rapid and efficient screen for the presence of mutations. Genomics 1992; 13: 441-443.

94 Liu Q, Sommer SS: R estriction endonuclease fingerprinting: a sensitive method for screening mutations in long, contiguous segments of DNA. Biotechniques 1995; 18: 470-477.

95 Cotton RGH, Rodrigues NR, Campbell R D : R eactivity of cytosine and thymine in single-base pair mismatches with hydroxylamine and osmium tetroxide and its application to the study of mutations. P roc N atl A cad Sci USA 1988; 85: 4397-4401.

96 Youil R, Kemper BW, Cotton RG: Screening for mutations by enzyme mismatch cleavage with T4 endonuclease. Proc Natl A cad Sci USA 1995; 92: 87-91.

97 M yers R M , L arin Z, M aniatis T: D etection of single base substitutions by ribonuclease cleavage at mismatches in R NA :D NA duplexes. Science 1985; 230: 1242-1246.

98 M cBride LJ, Koepf SM, Gibbs RA et al: A utomated DNA sequencing methods involving polymerase chain reaction. Clin Chem 1989; 5: 2196-2201.

99 Saiki RK, Walsh PS, Levenson CH, E rlich HA : G enetic analysis of amplified DNA with immobilized sequencespecific oligonucleotide probes. Proc $\mathrm{N}$ atl A cad Sci USA 1989; 86: 6230-6234.

100 N ewton CR, G raham A, H eptinstall LE et al: A nalysis of any point mutation in DNA. The amplification refractory mutation system (A R M S). Nucleic A cids Res 1989; 17: 2503-2516.

101 Grossman PD, Bloch W, B rinson E et al: High-density multiplex detection of nucleic acid sequences: oligonucleotide ligation assay and sequence-coded separation. N ucleic A cids Res 1994; 22: 4527-4534.

102 Gasparini $P$, Bonizzato A, Dognini M, Pignatti PF: $R$ estriction site generating-polymerase chain reaction ( $R$ G -PCR ) for the probeless detection of hidden genetic variation: application to the study of some common cystic fibrosis mutations. M ol Cell Probes 1992; 6: 1-7.

103 Wu DY, Wallace D B: The ligation amplification reaction ( $L A R$ ) - A mplification of specific DNA sequences using sequential rounds of template-dependent ligation. G enomics 1989; 4: 560-569.

104 Syvanen A-C, A alto-Setala K, Harju L, Kontula K, Soderlund $\mathrm{H}: \mathrm{A}$ primer-guided nucleotide incorporation assay in the genotyping of apolipoprotein E. G enomics 1990; 8: 684-692.

105 K uppuswamy M N, Hoffmann JW, K asper CK, Spitzer SG, Groce SL, Bajaj SP: Single nucleotide primer extension to detect genetic diseases: Experimental application to hemophilia B (factor IX), cystic fibrosis genes. Proc Natl A cad Sci USA 1991; 88: 1143-1147.
106 Jalanko A, K ere J, Savilahti E et al: Screening for defined cystic fibrosis mutations by solid-phase minisequencing. Clin Chem 1992; 38: 39-43.

107 Nickerson DA, Kaiser R, Lappin S, Stewart J, Hood L, $L$ andegren $U$ : A utomated DNA diagnostics using an E LISA -based oligonucleotide ligation assay. Proc $\mathrm{N}$ at A cad Sci USA 1990; 87: 8923-8927.

108 Nickerson DA, Whitehurst C, B oysen C, Charmley $P$, $K$ aiser R, Hood L: Identification of cluster of biallelic polymorphic sequence-tagged sites (pSTSs) that generate highly informative and automatable markers for genetic linkage mapping. G enomics 1992; 12: 377-387.

$109 \mathrm{~K}$ wok P-Y, G remaud M F, Nickerson DA , H ood L, O Ison $M V$ : A utomatable screening of yeast artificial-chromosome libraries based on the oligonucleotide-ligation assay. G enomics 1992; 12: 935-942.

110 Kobayashi M, Rappaport E, Blasband A et al: Fluorescence-based D NA minisequence analysis for detection of single-base changes in genomic DNA. Mol Cell Probes 1995; 9: 175-182.

111 Fahy E, Nazarbaghi R, Zomorrodi M et al: Multiplex fluorescence-based primer extension method for quantitative mutation analysis of mitochondrial DNA and its diagnostic application for A Izheimer's disease. Nucleic A cids Res 1997; 25: 3102-3109.

112 B row MA, O Idenburg MC, Lyamichev $V$ et al: Differentiation of bacterial 16S rRNA genes and intergenic regions and $M$ ycobacterium tuberculosis kat $G$ genes by structure-specific endonuclease cleavage. J Clin Microb 1996; 34: 3129-3137.

113 Shuber AP, Michalowsky LA, Nass GS et al: High throughput parallel analysis of hundreds of patient samples for more than 100 mutations in multiple disease genes. H um Mol G enet 1997; 6: 337-347.

114 Ellison J, D ean M, G oldman D: E fficacy of fluorescencebased PCR-SSCP for detection of point mutations. B iotechniques 1993; 15: 684-691.

115 I wahana H, Y oshimoto K, M izusawa N, Kudo E, I takura M: Multiple fluorescence-based PCR-SSCP analysis. B iotechniques 1994; 16: 296-305.

116 I wahana $H$, A dzuma K, Takahashi $Y$, Katashima $R$, Yoshimoto K, I takura M: Multiple fluorescence-based PCR-SSCP analysis with postlabeling. PCR M eth Appl 1995; 4: 275-282.

$117 \mathrm{H}$ aris II, G reen PM, B entley D R, G iannelli F: M utation detection by fluorescent chemical cleavage: application to hemophilia B. PCR M eth A ppl 1994; 3: 268-271.

118 Ellison J, Squires G, Crutchfield C, G oldman D: D etection of mutations and polymorphisms using fluorescencebased dideoxy fingerprinting F-ddF. Biotechniques 1994; 17: 742-753.

119 Fortina $\mathrm{P}$, Conant R, Parrella T et al: Fluorescence-based, multiplex allele-specific PCR (MA SPCR) detection of the $\Delta \mathrm{F} 508$ deletion in the cystic fibrosis transmembrane conductance regulator (CFTR) gene. $\mathrm{Mol}$ Cell Probes 1992; 6: 353-356.

120 Livak KJ, Flood SI, Marmaro J, Giusti W, Deetz K: O ligonucleotides with fluorescent dyes at opposite ends provide a quenched probe system useful for detecting PCR product and nucleic acid hybridization. PCR M eth A ppl 1995; 4: 357-362. 
121 Wittwer CT, Herrmann M G, M oss A A, R asmussen R P: Continuous fluorescence monitoring of rapid cycle D NA amplification. Biotechniques 1997; 22: 130-138.

122 Sagerstrom CG, Sun BI, Sive HL: Subtractive cloning: past, present, and future. Ann Rev Biochem 1997; 66: 751-783.

123 von Stein OD, Thies WG, Hofmann M : A high throughput screening for rarely transcribed differentially expressed genes. Nucleic Acids Res 1997; 25: 2598-2602.

124 M atz M, U sman N, Shagin D, B ogdanova E, L ukyanov S: O rdered differential display: a simple method for systematic comparison of gene expression profiles. Nucleic A cids Res 1997; 25: 2541-2542.

125 Zhang L, Z hou W, Velculescu VE et al: G ene expression profiles in normal and cancer cells. Science 1997; 276: 1268-1272.

126 Velculescu VE, Zhang L, Vogelstein B, K inzler KW: Serial analysis of gene expression. Science 1995; 270: 484-487.

127 Velculescu VE, Z hang L, Z hou W et al: Characterization of the yeast transcriptome. Cell 1997; 88: 243-251.

128 Wetmur JG: DNA probes: applications of the principles of nucleic acid hybridization. Crit R ev B iochem $M$ ol Biol 1991; 26: 227-259.

129 Luckey J, D rossman H, Kostichka T, Smith LM : Highspeed DNA sequencing by capillary gel electrophoresis. M eth Enzymol 1993; 218: 154-172.

130 Liu M S, R ampal S, E vangelista R A, L ee GC, Chen FT: $D$ etection of amplified $Y$ chromosome-specific sequence by capillary electrophoresis with laser-induced fluorescence. Fertil Steril 1995; 64: 447-451.

131 Woolley AT, M athies RA : U Itra-high-speed D NA fragment separations using microfabricated capillary array electrophoresis chips. Proc Natl A cad Sci USA 1994; 91: 11348-11352.
132 Woolley A, Mathies RA: U ltra-high-speed DNA sequencing using capillary electrophoresis chips. A nal Chem 1995; 67: 3676-3680.

133 Fung EN, Young ES: High-speed DNA sequencing by using mixed poly(ethylene oxide) solutions in uncoated capillary columns. A nal Chem 1995; 67: 1913-1919.

$134 \mathrm{M}$ athies R A, H uang X C: C apillary array electrophoresis: an approach to high-speed, high-throughput DNA sequencing. Nature 1992; 359: 167-169.

135 Clark SM, Mathies R A : High-speed parallel separation of DNA restriction fragments using capillary array electrophoresis. A nal Biochem 1993; 215: 163-170.

136 Bashkin J, M arsh M, Barker D, Johnston R: DNA sequencing by capillary electrophoresis with a hydroxyethylcellulose sieving buffer. Appl Theor Electrophor 1996; 6: 23-28.

137 Bashkin J, Solomon N, Erndt N et al: DNA sequencing with a multi-capillary array system. Microbiology Comparative $\mathrm{G}$ enomics 1997; 2: A 178.

$138 \mathrm{M}$ ansfield ES, Vainer M, Enad S et al: Sensitivity, reproducibility and accuracy in short tandem repeat genotyping using capillary array electrophoresis. Genome Res 1996; 6: 893-903.

$139 \mathrm{M}$ ansfield E S, Vainer M , H arris DW et al: R apid sizing of polymorphic microsatellite markers by capillary array electrophoresis. J Chromatogr A 1997; 781: 295-305.

140 Ramsay G: DNA chips: State-of-the-art. Nat B iotech 1998; 16: 40-44.

141 Schafer A J, Hawkins J R: DNA variation and the future of human genetics. Nat Biotech 1998; 16: 33-39.

$142 \mathrm{M}$ arshall $\mathrm{A}$, Hodgson J: DNA chips. A $\mathrm{n}$ array of possibilities. Nat Biotech 1998; 16: 27-31.

143 B rown $P O, H$ artwell L: G enomics and human disease variations on variation. $\mathrm{N}$ at $\mathrm{G}$ enet 1998; 18: 91-93. 